\title{
9 Scenes from a Marriage: The Age of Innocence as Discourse on the Transactional Value of Marriage
}

\section{Introduction}

Edith Wharton's 1920 novel The Age of Innocence ${ }^{1}$ is an innovative masterwork of tension and suspense; even the most domestic of its descriptions only heighten the reader's anticipation to find out what happens next. Frankly, it does not have the most unusual plot: a privileged young man marries one woman out of duty while believing he is in love with an exotic yet inaccessible other, and is forced to deal with the emotional and social consequences of the choices he makes for the rest of his life. Indeed, the themes of vanity and fallibility against the passage of time have been covered in long form by such heavy-hitters as Johann Wolfgang von Goethe, Marcel Proust, and Henry James. Yet The Age of Innocence is remarkable in its expression of the at-the-time insignificant moments which ultimately define a person's, marriage's, or culture's destiny. Wharton's contribution to the novelistic genre comes from the singular and thoughtful way she builds psychological tension through narrative focalization, thus allowing characterization and discourse to emerge through connecting with her reader's knowledge as well as her own lived experience.

Through establishing how Wharton explores a complex marital situation through a selective inclusion of significant cultural forces such as visual arts and earlier American literature into the narrative and builds mood through expanding interpretative spaces at key junctures in the novel, we can establish how The Age of Innocence stands as a powerful and still-influential document on the nature of transaction in marriage discourse in $20^{\text {th }}$-century American literature. This chapter will therefore present both biographical and literary historical data that establishes the context for Wharton's work. It will also briefly introduce and explore some cultural developments of the early $20^{\text {th }}$ century, such as the rise of psychoanalysis and secularization, which itself might be understood as transactional in nature, that might have impacted a contemporary audience's awareness of marriage discourse. These will then inform an interpreta-

1 All primary quotations from The Age of Innocence are taken from Edith Wharton, The Age of Innocence (New York: Penguin Classics, 1996 [1920]).

Ә OpenAccess. () 2021 Jessica Allen Hanssen, published by De Gruyter. (cc) BY-NC-ND This work is licensed under the Creative Commons Attribution-NonCommercial-NoDerivatives 4.0 International License. 
tive analysis built on a close reading of key elements of the marriage of protagonist Newland Archer and his wife, May Welland Archer, in The Age of Innocence, leading to a thus-informed discussion of the novel's significance to marriage discourse in later $20^{\text {th }}$-century American fiction.

\section{Wharton's Tableau Vivant}

Edith Wharton's place in American society, born in Old New York and raised among a moneyed and privileged elite yet denied a formal education, as would have been proper for women of her class and time, led her to struggle as a younger woman with a feeling of living the tableau vivant-living in imitation of the real thing, as numerous biographers such as R. W. B. Lewis and more recently Hermione Lee have observed. ${ }^{2}$ She uses the novel form as a means for narrativizing her internal conflict and as a protest against it. Wharton's descriptive yet exacting writing style is remembered not least for her representation, through words, of the tableau vivant, the living picture. The tableau vivant was a popular form of entertainment in the $19^{\text {th }}$ century, in which people would don elaborate costumes and pose as living waxworks in front of carefully constructed sets intended to represent paintings. For example, one of her most enduring characters, Lily Bart of The House of Mirth (1902), ${ }^{3}$ famously participates in a tableau vivant and enjoys being on display for her friends to admire, but when the admiration stops, so does her sense of wellbeing, with disastrous results.

Wharton herself was the subject of numerous portraits as an infant and child, as though her principal value was to sit still and look pretty, without too much thought given to what she might have to say. Emily J. Orlando, having studied Wharton's attitude and ideas on visual art, notes that Wharton's heroines progress "from victim to agents in the visual marketplace" ${ }^{4}$ and that she often alludes to art and art collecting as part of a "scathing critique" of a male-centered society. ${ }^{5}$ The very title The Age of Innocence is taken from a 1788 painting by Sir Joshua Reynolds (Fig. 1), who was much admired by Wharton's fellow New Yorker Washington Irving and his London social set, notably

2 Richard Warrington Baldwin Lewis, Edith Wharton: A Biography (New York: Harper \& Row, 1975); Hermione Lee, Edith Wharton (New York: Vintage Books, 2008).

3 Edith Wharton, The House of Mirth (New York: Charles Scribner's Sons, 1905).

4 Emily J. Orlando, Edith Wharton and the Visual Arts (Tuscaloosa: University of Alabama Press, 2007), 24.

5 Orlando, Visual Arts, 4. 
Charles Leslie and Sir Walter Scott (an author young Edith was expressly forbidden from reading until she was married ${ }^{6}$ ). The painting is of a young girl with reddish hair, perhaps five or six years old and not unlike Wharton herself at about that age (Fig. 2), looking off into the distance as though lost in thought. By using this painting as the starting point for her novel, Wharton ironically suggests that one is innocent, or devoid of the necessity of social code, only in childhood; that there can be no "age of innocence" beyond that point, and especially within the context and boundaries of marriage. Yet even the child, whom we love to believe is devoid of code and can be read like a book, has her own secret thoughts. Wharton herself reflected wistfully over her own childhood: "I have often sighed, in looking back at my childhood, to think how pitiful a provision was made for the life of the imagination behind those uniform brownstone facades," 7 that irony being that this sentiment was brought on by a memory of seeing her first courtesan glamorously debarking a brougham at seventeen, the forms and colors of the woman and her carriage moving young Edith in their "elegance and mystery," but being sharply told to turn her head away by her mother, ${ }^{8}$ as though profession and agency are contagious and visually transmitted. No matter how hard Newland Archer, May Welland Archer, or Wharton herself try to remember a time of innocence, once we leave childhood it is gone from us forever, if it ever existed in the first place. For women-and, not without connection but also not within the scope of this discussion, the enslaved-, this change was traditionally further signaled and cemented by the adoption of her husband's family name. The static image of the young girl, the very opposite of the tableau vivant motif she later became famous for, sends all of these messages at the same time.

Fortunately for American literature, Wharton received an early opportunity to travel abroad, thus inspiring her life-long interest in art and architecture and her future aesthetic sensibilities. Biographer Hermione Lee refers to Wharton's move to Europe when Edith was four years old as "the crucial first moment," when "nothing was the same afterwards." 9 She gained, even at such a young age, a sense of story and grandeur that she carried with her throughout her life, as reflected in her writing. Upon her return to America, and when beginning her career, Wharton sought to conquer what she saw as the complacency of

6 Lee, Edith Wharton, 38.

7 Edith Wharton, “A Little Girl's New York,” Harper’s Magazine 176 (March 1938): 356-364, repr. The Age of Innocence: A Norton Critical Edition, ed. Candace Waid (New York: W. W. Norton, 2002), 232-247. Subsequent citations refer to the Norton edition.

8 Wharton, “Little Girl's New York,” 235.

9 Lee, Edith Wharton, 16. 


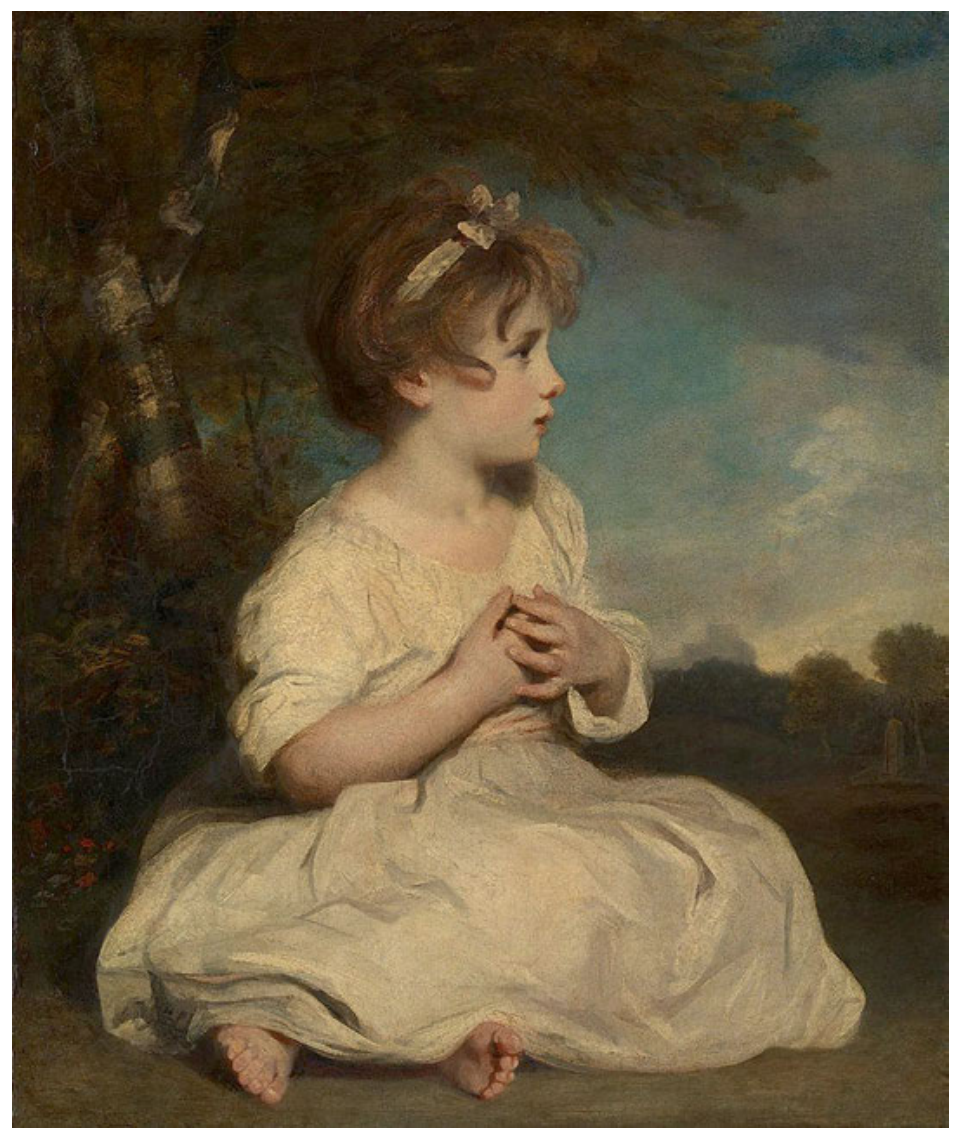

Fig. 1: The Age of Innocence by Joshua Reynolds (1788).

her own class toward matters of genuine importance, such as art, literature, philosophy, and science. Her writings on design and architecture, both American and European, were particularly well informed and influential, ${ }^{10}$ as was her war reportage from France, as Peter Buitenhuis documents. ${ }^{11}$ Her unique vantage, as well as her undeniable curiosity about the world around her, led her to become one of the most astute observers of society's manners and mores, both in fiction and in non-fiction.

10 Edith Wharton and Ogden Codman Jr., The Decoration of Houses (New York: Charles Scribner's Sons, 1897).

11 Peter Buitenhuis, "Edith Wharton and the First World War," American Quarterly 18, no. 3 (Autumn 1966): 493-505. 


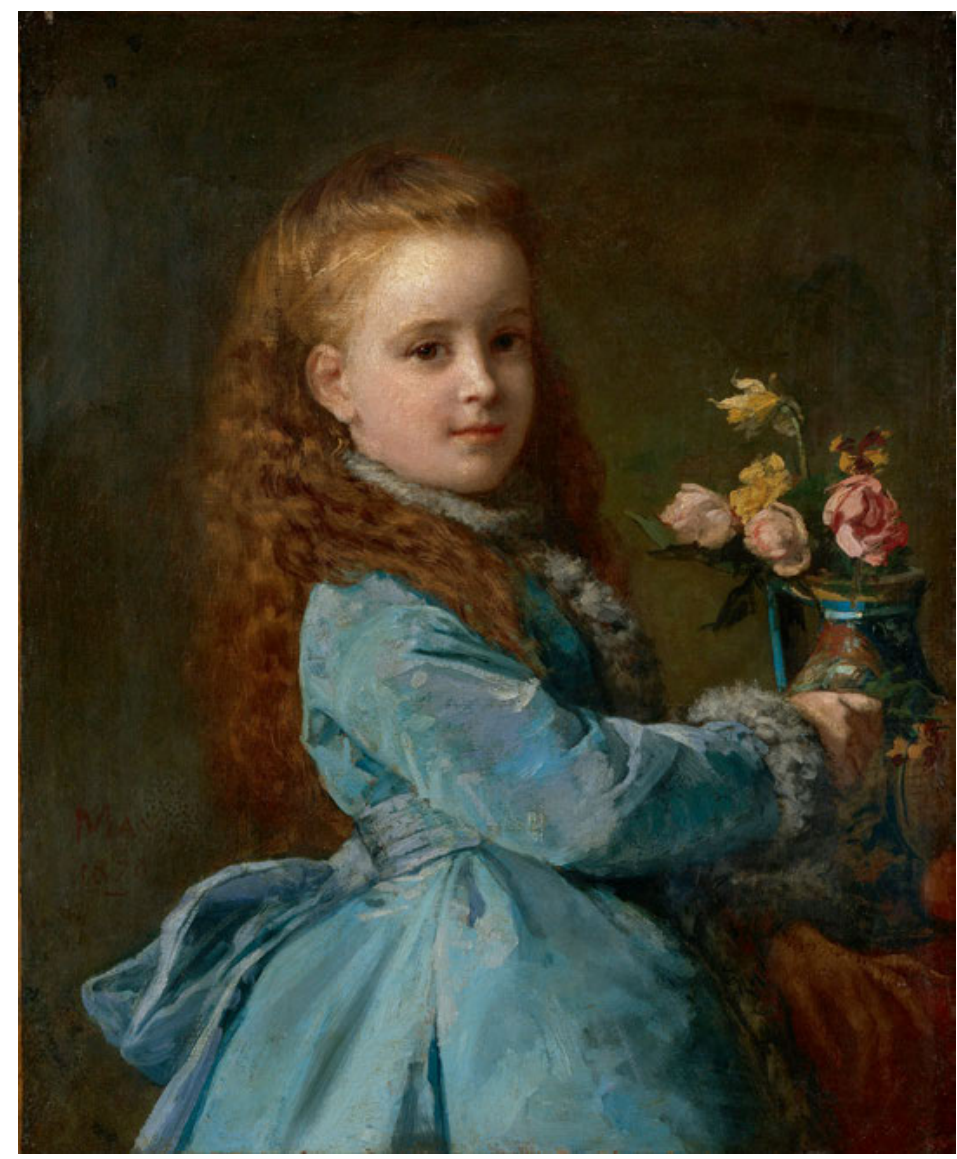

Fig. 2: Edith Jones at Age Five by Edward Harrison May (1870).

\section{The Age of Innocence (1920)}

The Age of Innocence is Wharton's eighth full-length novel and certainly her best known. It elegantly portrays desire and betrayal in 1870s New York, a setting rife with social and economic anxiety, even among the upper classes. The novel begins as Newland Archer, a young lawyer and avid man-about-town, prepares to marry May Welland, a young debutante from a respectable and wealthy old family. Their marriage would have been completely conventional and expected, and the prospect of it was welcomed by all as a means of continuance of the established social order. Before their engagement is announced, however, he meets May's cousin, the mysterious Countess Ellen Olenska, who has returned to 
New York after a long and somewhat scandalous absence, and Ellen's nonconventional style and suggestion of sexual liberation instantly appeal to Newland. The conflict of the novel arises as Newland attempts to balance his desire for Ellen with his responsibility to his (now) wife May and the emotional challenges he encounters as he naively attempts to manipulate the world to his liking.

The contemporary reception for The Age of Innocence was overwhelmingly positive, as Helen Killoran observes. ${ }^{12}$ Critics noted the novel's accurate attention to literary craft, precise attention to details of setting, and its historically accurate encapsulation of a changing American way of life. ${ }^{13}$ It seems, however, that many contemporary readers, doubtlessly seduced by the fantastic descriptions of Gilded Age fashion or the encoded entendres of 1870s upper-class society, might have missed the novel's sharp critique of its characters and their culture: when The Age of Innocence won the 1921 Pulitzer Prize, it was commended for being "the American novel published during the year which shall best present the wholesome atmosphere of American life, and the highest standard of American manners and manhood." 14 Clearly, Wharton did not mean for Newland and May Archer's decadent lifestyle or loveless, transactional marriage to present any kind of ideal, and wrote (in a letter to Sinclair Lewis): "When I discovered that I was being rewarded-by one of our leading Universities-for uplifting American morals, I confess I did despair."15

\section{Wharton's Feminism}

Wharton certainly observed the societal shift between the late $19^{\text {th }}$ and early $20^{\text {th }}$ centuries when it came to women's roles in marriage. Françoise Basch provides a comprehensive historical review of the various movements and ideologies that are the background for the primary setting of $A g e,{ }^{16}$ including the various forms of institutional oppression (economic, hegemonic, and marital) that many early American feminists fought against, but there is scant evidence that

12 Helen Killoran, The Critical Reception of Edith Wharton (Rochester, NY: Camden House, 2001).

13 Killoran, Critical Reception, 90.

14 Mike Pride, "Edith Wharton's 'The Age of Innocence' Celebrates its 100th Anniversary," The Pulitzer Prizes, https://www.pulitzer.org/article/edith-whartons-age-innocence-celebratesits-100th-anniversary.

15 Pride, "100th Anniversary."

16 Françoise Basch, "Women's Rights and the Wrongs of Marriage in Mid-Nineteenth-Century America," History Workshop Journal 22, no. 1 (Autumn 1986): 18-40. 
Wharton was much engaged with these or with their impact on the emergent idea of the "New Woman." She had little use for outward manifestations of feminist ideology and was known to have refuted these in her personal ${ }^{17}$ and professional $^{18}$ correspondence. Wharton's relationship to the feminism of her time was indeed complex, and not always as strident as a contemporary reader might prefer it to have been. One might even call it ambivalent. There is, however, also a subtle feminist discourse at work which permeates and influences Wharton's approach to narrative. Her feminism, if we can even call it that, is a quiet one, which reflects the complexities of the lived experience of women rather than treating them as either victims or proto-New Woman resistance fighters. Other critics have called attention to Wharton's engagement with the "New Woman" archetype, including, among others, Ellen Dupree, ${ }^{19}$ and of particular relevance to this discussion, Sevinç Elaman-Garner, who claims that the juxtaposition of "the multiplicity of contending voices and perspectives on women, marriage and divorce," ${ }^{20}$ particularly regarding Ellen Olenska, adds nuance and depth to the archetype exactly because it does not present a clear or stereotypical vision of her intrinsic motivation. Wharton's fiction, and The Age of Innocence in particular, portrays women as complex characters who undertake various types of rebellion and must endure the consequences of their choices, just as the men of their set must; Wharton saw authentic characterization of sensitive and courageous people as her literary project, ${ }^{21}$ and the success of this project stands as a testament to her lived experience, if not necessarily her stated values.

Again, it is not the intention of this chapter, or within its scope, to present a general overview of all the gender studies that have influenced a feminist reading of Wharton, ${ }^{22}$ but a brief consideration of the impact of recent gender studies of Wharton is nonetheless essential. In particular, the 1991 study by Carol J. Sin-

17 Lewis, Biography, 476.

18 Edith Wharton, The Writing of Fiction (New York: Charles Scribner's Sons, 1925).

19 Ellen Dupree, "The New Woman, Progressivism, and the Woman Writer in Edith Wharton's 'The Fruit of the Tree,”' American Literary Realism, 1870-1910 31, no. 2 (Winter 1999): 44-62. 20 Sevinç Elaman-Garner, "Contradictory Depictions of the New Woman: Reading Edith Wharton's The Age of Innocence as a Dialogic Novel," European Journal of American Studies 11, no. 2 (Summer 2016): 17.

21 Wharton, Writing of Fiction, 20 -21.

22 See Sandra M. Gilbert and Susan Gubar, The Madwoman in the Attic: The Woman Writer and the Nineteenth-Century Literary Imagination (New Haven, CT: Yale University Press, 1979); Elaine Showalter, Sexual Anarchy: Gender and Culture at the Fin de Siècle (New York: Penguin Books, 1991); Cynthia Griffin Wolff, A Feast of Words: The Triumph of Edith Wharton (New York: Oxford University Press, 1977). 
gley and Susan E. Sweeney of "anxious power"23 in Wharton's short story "Pomegranate Seed" (1931) becomes relevant here. For Singley and Sweeney, this "anxious power" derives in part from Wharton's personal "ambivalence toward the forbidden power of language" as stemming from a lingering childhood trauma, ${ }^{24}$ and that the various actions women take in this story-be they reading, writing, or even dying-"also signa[1] Wharton's ambivalence toward female art and authorship" 25 and that, notably, any act of a woman's creative fulfillment comes at a cost. In Age, which comes a full ten years before "Pomegranate Seed," Wharton does not yet broach the theme so directly, but Age nevertheless engages the "forbidden power of language"; much of this engagement, and thus its "anxious power," takes place in the focalization, and not in the plot itself.

\section{Early Literary Precedents}

While Wharton's themes, style, and attention to focalization have frequently been compared to her relative contemporaries, notably Henry James, to whom this chapter will return, a relatively overlooked but potentially fruitful vein of comparison perhaps reaches back still further, to Nathaniel Hawthorne in particular. Although they do not share the same gender, social, or economic backgrounds, or the same historical context for their fiction, they both share an emphasis on the lived experience, one which returns frequently to the intricacies of marriage and the problems of choice. They both also use their historically centered fiction to tell stories about present-day America, such as Hawthorne did in The Scarlet Letter (1850), in which he used the background of colonial America and especially the historical context of the Salem witch trials to explore the limitations of religion and sexual liberation in his contemporary reality, ${ }^{26}$ and also in short stories such as "The Minister's Black Veil" (1832) ${ }^{27}$ and "Young Goodman Brown" (1835). ${ }^{28}$

23 A phrase itself adapted from Gilbert and Gubar, Madwoman.

24 Carol J. Singley and Susan Elizabeth Sweeney, eds., Anxious Power: Reading, Writing, and Ambivalence in Narrative by Women (New York: State University of New York Press, 1993), 197. 25 Singley and Sweeney, Anxious Power, 214.

26 Nathaniel Hawthorne, The Scarlet Letter, 1850, vol. 1 of The Centenary Edition of the Works of Nathaniel Hawthorne, ed. William Charvat et al., 23 vols. (Columbus: Ohio State University Press, 1962-1997).

27 Nathaniel Hawthorne, “The Minister’s Black Veil,” 1836, in Twice-Told Tales, vol. 9 of The Centenary Edition of the Works of Nathaniel Hawthorne, ed. William Charvat et al., 23 vols. (Columbus: Ohio State University Press, 1962-1997), 37-53. 
Additionally, both Wharton and Hawthorne share a keen awareness of the connection of visual art to the written narrative; Rita K. Gollin, in her essay studying Hawthorne's relationship to the visual arts, notes that "Nathaniel Hawthorne was born into a confident and rapidly expanding America where ... there were no major collections of art, no government patronage or the arts nor generous private patrons." ${ }^{29}$ His movement toward the exploration of American landscapes and themes was as reactionary as it was essential; for Hawthorne, "America” itself came to represent freedom from a stifling artistic tradition and also a safe distance from which to reflect upon the rest of the artistic universe. This awareness of Hawthorne's artistic concerns speaks to Wharton's approach to her own fiction, in which she frequently incorporates elements of the rest of the artistic world, for example painting, sculpture, music, and architecture, as a metaphor for the opposition of the static and the dynamic, in literature as well as in culture. Having navigated a by-then more explicitly developed system of patronage and the business side of the American arts world than Hawthorne, however, Wharton also includes reference to these realities as essential context for her outlook on the connection of art and society.

Finally, it is worth noting, by way of comparison, that Hawthorne's approach to the representation of marriage, feminism, and women's rights, which can be seen in his short stories, novels, and essays as indirect but palpable social critique, predates and clearly informs Wharton's. Hawthorne certainly draws upon an "anxious power" in his characterization of Hester Prynne and Goodwife Faith Brown, and many other women characters. In this sense, Wharton's approach to feminism builds on Hawthorne's early awareness and also informs it from her lived experience, as Margaret B. McDowell observes: "because of her sympathy with her women characters and her insight into their lives, she reveals an implicit feminism as they relate, ordinarily at some disadvantage, to individual men or to a society which men control and dominate."30

For these reasons, it is notable that Wharton staged her contemporary war novel in Antebellum America, as this bears structural and narrative similarity to Hawthorne's The Marble Faun (1860), a novel which also transposes decidedly American concerns about art, justice, and morality to, in this case, Italy, and,

28 Nathaniel Hawthorne, "Young Goodman Brown," 1835, in Mosses from an Old Manse, vol. 10 of The Centenary Edition of the Works of Nathaniel Hawthorne, ed. William Charvat et al., 23 vols. (Columbus: Ohio State University Press, 1962-1997), 74-90.

29 Rita K. Gollin, "Hawthorne and the Visual Arts," in A Historical Guide to Nathaniel Hawthorne, ed. Larry J. Reynolds (Oxford: Oxford University Press, 2001), 109.

30 Margaret B. McDowell, "Viewing the Custom of Her Country: Edith Wharton's Feminism," Contemporary Literature 15, no. 4 (Autumn 1974): 521-538. 
revealingly, a novel that everyone at the Archer house has read..$^{31}$ The Age of Innocence, in fact, bears out more than a little similarity to Hawthorne's last romance, both of which chronicle the nature of a closely quartered, never-consummated, bizarre love triangle as it plays out (or not) as war becomes imminent. The connection of the Italian setting of The Marble Faun to The Age of Innocence therefore provides revelatory context for Newland Archer's actions and behavior.

Throughout the novel, Newland Archer connects his romantic impulses with Italy, imagining that one day he and May will "read Faust together ... by the Italian lakes." 32 He does not, of course, pull this association out of thin air; he learns it at the opera house, that palace of illusion and shimmer which Wharton's narrator witheringly describes as a world in which the "German text of French operas sung by Swedish sopranos should be translated into Italian for the clearer understanding of English-speaking audiences." ${ }^{33}$ He never does make it to Italy with May, however, as reality kicks in and their honeymoon tour of Europe consists largely of duty calls to distant family and visits to dressmakers and tailors. The real reason that they do not go to Italy, however, is that Newland is unable to imagine his naïve May in "that particular setting"34; it is as though for him Italy has connotations with which he does not wish to burden her-or himself. Italy becomes for Newland the sought-for, an exercise in self-denial.

This self-denial also carries, to Wharton's contemporary reader, deep psychoanalytic connections to, for example, Freud's fear of train travel as he describes it in The Interpretation of Dreams (1901), which he eventually, he claims, conquers by tracing it to an early incident in which he became aroused observing his (pregnant) mother washing herself on a train. Before he conquered his fear, however, it prevented Freud from traveling to Rome to look upon the monuments, which was one of his most ardent desires. Although Newland does manage to make the European passage, he does not make it to Italy, representative of an unconscious repression of his desires and also, potentially, of the stranglehold his mother and her domineering ways have on his marriage and other life choices.

By the time Newland and May are well established in marriage, and Archer is deep into his infatuation with Ellen Olenska, he still holds the belief that somewhere outside of the confines of America, there is some kind of magical country where he could be free to love Ellen without restraint. In chapter 29,

31 Wharton, Age, 27.

32 Wharton, Age, 6.

33 Wharton, Age, 4.

34 Wharton, Age, 159. 
tucked inside May's wedding-gift carriage with Ellen, he attempts to express his yearning to physically abandon his reality. While he is unable to properly articulate his desire, Ellen asks directly: "Is it your idea that I should live with you as your mistress-since I can't be your wife?"35 Her ability, whether deriving from more or less sophistication than Archer possesses, to succinctly state the facts, and particularly the word "mistress," without any sort of ambiguity shocks Newland into a revelation, as he then declares to Ellen: "I want-I want somehow to get away with you into a world where words like that-categories like that-don't exist. Where we shall be simply two human beings who love each other, who are the whole of life to each other, and nothing else on earth will matter." 36 Ellen immediately calls his bluff, however, and seems to anticipate his association of romance and lack of social code with the Mediterranean: "Oh, my dearwhere is that country? Have you ever been there ... I know so many who have tried to find it; and believe me, they all got out at wayside stations: at places like Boulogne, or Pisa, or Monte Carlo." ${ }^{37}$ Ellen, with this brief catalog, deflates Newland's sincere-sounding desire as the kind of Eurotrash fantasy that only a naïve American could muster. While Hawthorne's young artists go to Rome seeking artistic-and social-freedom but find instead a world of darkness, lethargy, and seclusion, Wharton takes this idea one step further and does not allow Newland Archer the latitude to make his own discoveries. He is trapped in a world of his own creation but which is devoid of even fantasy. And while Newland's entire sense of well-being stems from having a comfortable place within a clearly defined social tradition, Ellen Olenska, as Cynthia Griffin Wolff notes, has "learned the terrible and inexorable toll that tradition takes," 38 also bearing similarities to other of Hawthorne's doomed pairings: Goodman Brown and Faith, Mr. Hooper and Elizabeth, or Arthur Dimmesdale and Hester Prynne.

Hawthorne, however, is not the only canonical American reference for The Age of Innocence, and in a world where the ancestors of the old Dutch "Patroons," synthesized into the cold yet essential social arbiters the van der Luydens, reign supreme, it is perhaps not surprising that Wharton would also reach to Washington Irving for inspiration, as he, too, was an astute participant in and chronicler of the social mores of the New York of his time. Notice, for example, the playful way Wharton incorporates "Rip Van Winkle," that fabled old man of Old New York, into the story. While Irving is mentioned only in passing as

35 Wharton, Age, 238.

36 Wharton, Age, 238.

37 Wharton, Age, 238-239.

38 Wolff, Feast of Words, 426. 
a writer that even (or only!) your mother can love, that Newland Archer's story drops off in chapter 33 when he learns of May's pregnancy and resumes in chapter 34-nearly thirty years after his marriage to May-structurally evokes the paralepsis of Rip's famous mountain siesta, and the refrain of "Why, this used to be one of the old Cesnola rooms!" 39 he hears at the Metropolitan Museum closely resembles Rip's discombobulated response, upon waking, to the metamorphosis of the King George The Third Inn to the Union Hotel, now replete with stars and stripes: "all of this was strange and incomprehensible." 40 For those who know and appreciate Irving's work and the American mythology he created, or even his life situation (in which, having experienced first a fall and then a stratospheric rise in social standing, he remained a lifelong bachelor after the tragic death of his fiancée), a whole story is told in the interstice between chapters 33 and 34.

As Rip does, Newland indeed "wakes up" in a new world, a New Land, even, and like Rip Van Winkle's framing narrator Geoffrey Crayon goes abroad to escape it, in his case to Paris, that old haunt of beauty and romance and decadence, but he cannot seem to shake the old social standards. At the moment when it is at last safe for Newland to express his true feelings for Ellen Olenska-May is dead, New York is on the far side of the Atlantic, and even his grown son Dallas approves of the reunion-Newland remains planted on a bench outside of Ellen's apartment building, content to let a closing curtain be his only sign of her existence. "It's more real to me here than if I went up," he says sitting there, articulating his life-long impulse to value the image of a thing more than the thing itself. ${ }^{41}$ This moment was foreshadowed in chapter 30 , when Newland Archer, two years after his marriage and desperately trying to conceal his growing distaste for May in what he saw as a "perpetual tepid honeymoon," ${ }^{22}$ insisted on opening the curtains to his library and looking out over the city of New York, on Washington Square, no less, on an icy night, breathing in the cold air while "getting the sense of other lives not his own, and a whole world beyond his world." ${ }^{43}$ He takes a particular delight in not looking at May while doing so, just as Rip takes delight in abandoning his wife, whose opinions he valued as much as Newland seems to value May's, for the cold and remote Catskills. It is, of course, notable that Irving presents Rip van Winkle's wife,

39 Wharton, Age, 284.

40 Washington Irving, "Rip Van Winkle," in The Sketch Book of Geoffrey Crayon, 1819-20, repr. The Legend of Sleepy Hollow and Other Stories: Or, The Sketch Book of Geoffrey Crayon, Gent., intro. Alice Hoffman (New York: Random House, 2001), 35.

41 Wharton, Age, 298.

42 Wharton, Age, 35.

43 Wharton, Age, 242. 
Dame van Winkle, as focalized through Rip's unfair and naïve perception of her as mean and shrewish, but also, quietly and from outside the narrative, allows the reader to appreciate her intellectual superiority, independence, and willingness to let Rip stew in his own juices; this duality informs Wharton's outlook on Newland and May's focalization as well. While Wharton's influences were broad, and also European, the deep structural connections to early American literature set the tone for and add rich context to her settings, social observations, and indirect characterizations.

\section{Metatextual Cultural Forces}

One of the many observations Wharton not only made but narrativized was the glacial pace at which large-scale societal shifts slowly but inevitably affect the insulated lives of her characters. The Age of Innocence comes at an interesting juncture when it comes to American attitudes on marriage. While it is mostly set in the 1870s (with a proleptic jump to the early 1900s at the very end) and documents the customs and conventions of its setting with precision, Age is nevertheless very much of its time in terms of its metatextual influences. The impact of psychoanalysis on the American cultural landscape, for example, began to become more pronounced in the early 1920s, while religious influence began to weaken somewhat. ${ }^{44}$ These forces, although neither of them are explicitly

\footnotetext{
44 The rise of psychoanalysis as a cultural force can be neatly tied to Freud's 1909 visit to the United States. By 1920, psychoanalysis was well established among the New York elite, as documented by Sanford Gifford, “The Psychoanalytic Movement in the United States, 1906-1991," in History of Psychiatry and Medical Psychology, eds. Edwin R. Wallace and John Gach (New York: Springer, 2008), 629-656. This timeline intersects with the rise of secularization as understood by Peter L. Berger as "the process by which sectors of society and culture are removed from the domination of religious institutions and symbols." Berger, The Sacred Canopy: Elements of a Sociological Theory of Religion (Garden City, NY: Doubleday, 1967), 107. While church remained a significant social class indicator in elite New York, it is notable that the Archers had a family pew at the most grand and prestigious of New York's Episcopal churches, Grace Church. It was completed in 1846, as was, just down Broadway, A. T. Stewart Dry Goods Store, a.k.a. the five-story "Marble Palace," the country's first department store, giving the ladies who lunch an equally grand place to shop while still dressed in their Sunday finest: see Harry E. Resseguie, “Alexander Turney Stewart and the Development of the Department Store, 1823-1876," Business History Review 39, no. 3 (Autumn 1965): 301-322. This apparent turn away from religion, or at least toward an equally appealing consumerism, only slightly anticipates Weber's later and influential theories about the Protestant ethic, a notion to which Wharton perhaps alludes: "in a world where all else had reeled on its foundations the 'Grace Church wedding' remained an unchanged institution." Wharton, Age, 284.
} 
mentioned much at all in Age, nevertheless reach a nexus within. Something is lost, and something is also gained, as one philosophy begins to overtake another, and The Age of Innocence dwells right at their intersection and places the transactional marriage of Newland Archer and May Welland right in this crucial cultural moment. In this sense, Newland and May, representing at times alternating outlooks on both tradition and possibility, and with the economic freedom to explore issues from more than one perspective, personalize a culture war that might not otherwise be immediately accessible.

Whereas religious tradition had generally been the significant organizational structure for one's life and a prime motivator for marriage, the turn of the $20^{\text {th }}$ century presents the rise of new ways to understand one's sense of self and which have implications on The Age of Innocence and its creation and examination of a marriage discourse. Although the novel's 1870s setting does not allow for direct engagement with behaviorism in the plot, the 1920 publication does invite metacontextual consideration of how psychological behaviorism, an offshoot of the rise of psychoanalysis in general, begins to displace religion and to infiltrate the function of marriage in the Archers' lives. Behaviorism in general seeks to externalize the inner life of the mind as a series of behaviors, which can then be classified and, potentially, understood as an evidence-based reasoning for learning through conditioning one's responses to one's environment. ${ }^{45}$ Pavlov's animal experiments, perhaps under his objection, nevertheless formed a strong contemporary basis for how human behavior can be conditioned, and James Watson's refinements were a hot subject for debate throughout the 1910 s. $^{46}$ Whereas psychology as a science was and is difficult for laypeople to grasp, behaviorism provided access to many of its tenets in a readily understood form. There is scant research to indicate that Wharton was much interested in the debate, but it is clear that she knew about it and applied this knowledge to Newland Archer's characterization, who drew on, in the classification of his social set, "the new ideas in his scientific books, and the much-cited instance of the Kentucky cave-fish, which had ceased to develop eyes because they had no use for them." 47 People, like a given species, can be understood, and they can also, upon necessity, adapt to their situation.

45 George Graham, "Behaviorism,” in Stanford Encyclopedia of Philosophy, ed. Edward N. Zalta, Stanford University, 1997-, article published May 26, 2000, last modified March 19, 2019, https:// plato.stanford.edu/archives/spr2019/entries/behaviorism/.

46 Richard F. Rakos, “John B. Watson’s 1913 'Behaviorist manifesto': Setting the Stage for Behaviorism's Social Action Legacy,” Revista Mexicana de Análisis de la Conducta 39, no. 2 (2013): 99 118.

47 Wharton, Age, 56. 
For someone like Newland, behaviorism functioned much like a religion, in that it provided a means of exploring the essence of personhood and routes to resolution, but with the added tangibility of reinforcement. Additionally, whereas the idea of sinfulness and (self-)deception had also traditionally been the realm of the church, and thus cloaked in mystery and ambiguity and relying upon an intercessory framework for redemption, the idea that one can identify and correct one's own unseemly behavior through self-introspection and direct action, without the potential discomfort of engagement with an intercessor, was undoubtedly a liberating concept for its practitioners. Similar to religion, behaviorism focuses on the ways in which a person can experience transformation, self-improvement, or change, but without the implied judgment of the church or its followers. For the upper-class characters Wharton writes about, in which the static immutability of wealth and status is key, true transformation, perhaps, is ultimately undesirable or even impossible, and at best it is conflated into economic transaction-one might "transform" oneself with a trip to Paris, a new jewel, a new carriage, a well-appointed study, or a new lover. Even as religion itself does not provide much social prestige to the novel's characters, it remains central to the function of high society as an outward symbol of conservatism, as a small price to pay for carrying on in one's private excesses. It is notable that the only time Newland attends church in the novel is on the occasion of his own wedding, and his discomfort is palpable.

Yearnings toward self-improvement are certainly implied in Age, and this is part of the reason that Newland and May drift apart. Newland's entire worldview, though deeply steeped in the traditional, is also informed by a scientist's desire to categorize and classify, and for Newland to be able to successfully achieve classification of others is a way for him to advance his sense of self and wellbeing, without necessarily having to reflect on his own behavior. The ways he treats May, other people, and especially Ellen Olenska are affected by Newland's tendencies toward the superficially categorical. Once he has categorized a person, his words, deeds, gifts, and so on all fall into order, or so he thinks, and he gets a certain patriarchal satisfaction from this. Part of Newland's problem is the way in which he assigns meaning to the things and people around him, as though he is classifying them for a collection before putting them away. Scholarly examination or meditation is not his style. While he is indeed a fast reader of people, perhaps coming from his perceived "intellectual and artistic superiority," ${ }^{48}$ he can be too hasty. Once he has placed a label on someone, the label becomes indelible, and in fact supplants the person in his mind. This is why, for

48 Wharton, Age, 7. 
example, he is unable to see Ellen's deep social insecurity and relative inexperience, he made up his mind from the first time he saw her black satin dress and her Josephine hairstyle that she was glamorous and exotic, as opposed to "innocent” May with her white dresses and pinned-up curls. Since the narrator is more sophisticated than Newland himself, we are able to sense the ambiguity of these symbols and images so much more readily than Newland, creating a sense of knowing and dramatic irony. And yet, the principles of behaviorism go two ways, and Newland rarely, and only at the novel's conclusion, turns to self-examination. His behaviorist tendencies, for the most part, focus only outward, toward what he can immediately grasp or control.

In this sense, May and Ellen both appear to be more comfortable with the introspective. What they individually want from Newland cannot be readily classified or hastily bought. May's outlook on her marriage is simultaneously more conservative and more liberal than Newland's. She knows the informal but fixed rules of marriage in her class and does not expect or need to challenge them. When she finds herself a victim of Newland's easy characterization of her as "innocent" of his indiscretion with Ellen, she takes comfort in her own intuitive sophistication and self-actualization and allows Newland the discomfort of coming to an independent realization that she does not actually depend on him for much of anything. Her wealth is independent, her social standing is her own: Newland has more at stake than she does and must change his behavior accordingly. Likewise, while Newland might have categorized Ellen as a fallen temptress that he could lift back into societal grace (and quietly receive gratitude for), this categorization does not take into account Ellen's deeply introspective nature and her trusting ability to relate her emotional state to others, including May, which also forces change on Newland's part. He could not conceive of them as united because he had separated them so strongly. Wharton's great irony here is that while impulses derived from behaviorism might have been appealing to men seeking a way to uphold a patriarchal order without the strictures of religious piety, it is the women in The Age of Innocence who demonstrate by far the deeper psychological awareness.

\section{Discussion: Transactional and Tangible Distance}

All of these factors-Wharton's upbringing, her artistic and literary influences, her rejection of politics, and her knowledge of how emergent cultural forces such as psychoanalysis can shape but not define a discourse-cumulatively enable The Age of Innocence to serve as a strong presentation of how the idea of distance, in setting, focalization, and symbolism, creates a sense of marriage 
as transactional. The social standard which Wharton so ably expresses in The Age of Innocence is based primarily on the idea of distance and the simultaneous but differently motivated drive each of the novel's main characters feel to maintain, above all, a sense of control through manipulating it. Pamela Knights ${ }^{49}$ has written extensively about the various social codes at play in the novel and how they serve to disembody the character from his or her life, but not with specific referent to the idea of distance. In order to describe the social code which defines Newland Archer and is simultaneously his undoing, Wharton relies on certain images to express this distance. In this brief discussion, I will seek to tie Wharton's various influences together in order to explore and illuminate specific examples of how the sensory elements of sport, flowers, and food function to enforce the ideas of transactional distance within the Archers' marriage.

Obviously, the image of archery is of primary importance, given the charactonym “Archer." A great deal of critical ink has been spilled describing the allegorical significance of Archer as it relates to May Archer's resemblance to Artemis, especially given Wharton's study of Frazer's The Golden Bough (1890, with a third and final version in 1906-1915), and frequent mythological allusions are made throughout the book to suggest that May is like Artemis, virgin goddess of the hunt. A similar comparison can be made with Newland Archer and Artemis's twin Apollo, also an archer, who was charged with, among many tasks, being the patron defender of herds and flocks; Archer's obsession with people, places, and things being "right” speaks to his role as society's shepherd. Here, however, the connection which Wharton wishes us to make is, of course, with Isabel Archer, heroine of Henry James's The Portrait of a Lady (1881). It is well established, notably by American feminist literary scholar Cynthia Griffin Wolff $^{50}$ and later by 19 th-century literary scholar Cushing Strout, ${ }^{51}$ that James was a profound influence on Wharton's subject matter and writing style, and Isabel Archer, James's fullest representation of the "true American girl," was widely admired by the international reading public as "the pride of America" and had become a well-known character in the newly developed American literature by the time Wharton began writing novels. There are obvious similarities in the setting and social milieu of The Portrait of a Lady and The Age of Innocence, yet

49 Pamela Knights, "Forms of Disembodiment: The Social Subject in The Age of Innocence," in The Cambridge Companion to Edith Wharton, ed. Millicent Bell (Cambridge: Cambridge University Press, 1995), $20-46$.

50 Wolff, Feast of Words.

51 Cushing Strout, “Complementary Portraits: James's Lady and Wharton's Age," in Edith Wharton's The Age of Innocence, ed. Harold Bloom (Philadelphia, PA: Chelsea House Publishers, 2005), 3-11. 
while Age is informed by Portrait, it does not seem derivative; Strout maintains that to see it this way is "patronizing" of Wharton and her achievements, or "merely being a clever disciple of James." 52 Wharton takes her Archer one step further than does James, and while conjuring up all the virtues of James's Isabel, adds to May a sense of artificiality which is no less "American" than her cheerfulness, self-confidence, or wholesomeness. Lacking none of Isabel Archer's outer qualities, but devoid of James's false and somewhat patriarchal perceptions about the "freedom" of the American girl, May Archer represents an updated image of manufactured femininity, offered up for consumption for a husband and a society who have no real understanding of the depth of her emotions. Everything from her appearance in the archery contest at the exclusive Newport Country Club (notably, a club to which Ellen Olenska did not belong), to her Parisian white summer dress and diamond arrow brooch, to Newland's internalized anger at his friend's admiration of her appearance, as though she exists and dresses only for Newland for to admire, symbolizes this duality. Yet just as archery looks easy until you try it, May's façade is flawless and hides great amounts of skill, patience, and determination. Even in her ribbon-accented corset, and while displaying perfect archer's form, she radiates the glow that comes from knowing that, even if Newland was no longer in the picture, her access to the club and its social set would remain, as well as that Newland is not as free to pursue Ellen as he thinks he might be because she also carries, unbeknownst to all except her, his child. Newland is free to categorize and interpret May however he likes, but his time is limited, and so she keeps her distance for now, knowing the exact speed at which her arrow will land.

Also expressing the discourse of marital distance through coded imagery is the frequent reference to various flowers and exotic foods. We use the phrase "hothouse flower" today to mean a cultivated, delicate personality that would not survive outside of its unnatural habitat, and, though not to the extent as in Wharton's day or the time of the novel, we still send flowers at times of social importance: courtship, weddings, childbirth, celebration, illness, and death. What do we value about a bouquet of flowers? They are fragrant, beautiful, and expensive. Grown in greenhouses or special fields as the objects of intense care, they are cut in their prime, and generally delivered by messenger, just to bring us temporary sensorial pleasure. We essentially enjoy their delicate corpses for a day or two and then toss them aside as soon as their mortality becomes too obvious. They are purely a metaphor for social transaction. In the 1882 reference work Our Deportment, which offers a guide to the "manners, conduct, and

52 Strout, "Complementary Portraits," 4. 
dress of the most refined society," John Young suggests that flowers can be as expressive of meaning as a poem, and he claims that there are specific meanings attached to certain flowers by "universal consent." 53 While some of the so-called meanings of flowers on his list go back to Roman times, others seem more arbitrary, yet the idea that a flower sends a certain encoded message is one that would certainly have resonated with Newland Archer's set.

The frequent and specific references to various flowers in The Age of Innocence sensorily capture the idea of the commodification of personality and Newland Archer's distance from the life around him. He chooses lily-of-the-valley to represent May Welland, sending her a delicately ribboned bunch every day, and bright yellow roses to represent Ellen Olenska, spontaneously sending her large bouquets with no card. He seems to believe that the lily-of-the-valley symbolizes May's innocence and purity, which he wants on schedule, while the yellow roses represent Ellen's exotic allure, which he wants at whim. Yet, as Edith Wharton, and anyone with her social background, likely knew from books such as Our Deportment, the lily-of-the-valley was widely understood to symbolize the return of happiness, ${ }^{54}$ while the yellow rose stood for the decrease of love. ${ }^{55}$ So Newland Archer manages to send one message while believing he is sending entirely another; the "innocence" of the novel's title is his.

In The Age of Innocence, the symbolic value of flowers frequently becomes lost, and in no place more so than at the end of Part I, in which Newland Archer stands at the altar waiting to be married. Whereas one would expect him to await his beloved bride May with excitement and eagerness, he instead finds himself noticing everything else around him, such as the music, the ghostly faces in the crowd, and the noises and murmurs in the air, and May herself is reduced to "a vision of a cloud of tulle and orange-blossoms floating nearer and nearer." I find this image to be rather horrific in its disambiguation of May, and while orangeblossoms are traditionally the flower of brides, representing chastity, ${ }^{56}$ there is something decidedly sinister in the defamiliarization of traditional American bridal imagery here, as though Newland wishes to disassociate himself with his marriage even before it occurs. Knights argues that at this point, the "signs come adrift from their meanings," 57 but it is not certain that they were ever connected for Archer. The irony of all this disassociation comes to him at the end of

53 John H. Young, Our Deportment; or, The Manners, Conduct and Dress of the Most Refined Society (New York: F. B. Dickerson \& Co, 1885), 126.

54 Young, Our Deportment, 417.

55 Young, Our Deportment, 420.

56 Young, Our Deportment, 416.

57 Knights, "Forms of Disembodiment," 35. 
the novel when he realizes "something he knew he had missed: the flower of life." 58 Which flower would that be? It is never stated.

One could make a similar case for the exotic foods served at the frequent parties Archer and his set ceaselessly attend and host. Content to dine on the humblest and most poorly prepared of meals while at home, Archer treats his dinner guests to asparagus "from Florida," terrapin soup, and the Roman punch which Mrs. Archer believes makes "all the difference." 59 Looking at what "Roman punch" would have been made of, it is an appallingly sweet, tasteless concoction of sweet wines, fruits, lemonade, merengue, and sugar; ${ }^{60}$ it does not sound appetizing in the slightest to a palate more sophisticated than a child's. Its appeal, apparently, comes from its fanciful service, in a bowl shaped to resemble "the heart of a red rose, or ... the bosom of a swan, or the cup of a lily, or the 'right little, tight little' life saving boat," the bowl itself being the finest china, glazed pottery, or even ice, ${ }^{61}$ and reserved for only this purpose. The exoticism of the foods, and his ability to afford to serve them, simultaneously emphasizes Archer's comfort with his posh surroundings and yet his need to fill his life with imported things and imported people: Ellen Olenska is the guest of honor at this particular "farewell” dinner. In Archer's world, people are also judged according to the kinds of food they serve and to which company they serve them: dining becomes a transaction of food for the pleasure of classification. For example, the van der Luydens, the absolute upper crust of New York society, are famous for rarely dining out, preferring their own dinner company to that of others. The matriarch Mrs. Manson Mingott, who is May and Ellen's grandmother (and a stand-in for Edith Wharton's own), is equally famous for the penury of her kitchen despite her vast bulk and fortune. The vulgar-yetaccepted Beauforts serve "hot canvas-back ducks and vintage wines"62 at their dinners, presumably to make up for Julius Beaufort's unknown social origins. May's mother Mrs. Welland serves meals utterly lacking in appeal but made up for in the amount of gossip that one might hear over her table. And social climbers like Mrs. Lemuel Struthers do not seem even to bother with meals at all but serve champagne to one and all! The people around Newland Archer oc-

58 Wharton, Age, 286.

59 Wharton, Age, 270.

60 "Real Roman Punch: How a Drink Made Exclusively for the Pope Became General," Morning Union 44, no. 5956, February 7, 1890, https://cdnc.ucr.edu/?a=d\&d=MU18900207.2.3\&e=---en20--1--txt-txIN--1.

61 Mary Elizabeth Wilson Sherwood, Manners and Social Usages (New York: Harper \& Brothers, 1887), 268.

62 Wharton, Age, 17-18. 
cupy themselves with assessing the meaning of the foods people serve with zeal, yet do not discuss these meanings publicly, for that would be an unspeakable violation of the unspoken social code of the List of 400 which defined their social status. The very phrase "keeping up with the Joneses," after all, was introduced into American slang as a reference to Edith Wharton's extended family, ${ }^{63}$ who would have known a thing or two about expensive parties and the transactional value of things that express distance.

By the end of the novel, Newland Archer recognizes that the various forms of distance in his life are in step with the changing society. Consider the marriage of his son Dallas to Fanny Beaufort, daughter of a scandalous, fallen man and his former mistress:

Nothing could more clearly give the measure of the distance that the world had travelled. People nowadays were too busy-busy with reforms and 'movements', with fads and fetishes and frivolities-to bother much about their neighbors. And of what account was anybody's past, in this kaleidoscope where all the social atoms spun around in the same place? ${ }^{64}$

With this observation, the idea of distance ironically brings us closer to the narrative than ever, as we recognize something of what we think of as our own cultural peculiarities. "Dash it, Dad, don't be prehistoric!" begs Dallas, ${ }^{65}$ failing to understand the engrained codes that keep Newland from making the move toward Ellen. Despite his obvious approval of the marriage of Dallas to Fanny, Newland cannot bring himself to apply the same standards to himself, choosing instead a stance of isolation that defies his own self-characterization as, above all, one who belongs.

\section{Conclusion}

This chapter has addressed the innovative ways in which The Age of Innocence by Edith Wharton develops a holistic and original discourse on American marriage through her simultaneous engagement with and disengagement from significant cultural forces such as visual arts, earlier American literature, and emerging 20th-century attitudes toward psychoanalysis and secularization, and exemplified this engagement with examples from the text in order to illumi-

63 Carol J. Singley, ed., A Historical Guide to Edith Wharton (Oxford: Oxford University Press, 2003), 5.

64 Wharton, Age, 291.

65 Wharton, Age, 293. 
nate the subtleties of her narrative focalization as they shape a transactional view on marriage. Thinking about The Age of Innocence from a historical standpoint, and by way of conclusion, one takes from Archer's final reflection on his distance from his own world-and his own marriage-a connection to Wharton's own post-war sense of distance, loss, and alienation. Written after she personally experienced the aftermath of World War I as a volunteer in the war relief effort, and also after the dissolution of her own marriage following her husband's extended mental illness and her own romantic affair, ${ }^{66}$ she struggled to reconcile the physical and emotional consequences of the war with the culture and lifestyle she had known before its start. An unfinished poem of hers simultaneously expresses her patriotism and her skepticism: "France! To give thee, o my more than country / Give thee of my blood's abundance all." ${ }^{67}$ In this sense, her conservative yet liberal concerns here anticipate those of the younger Lost Generation writers, who also found themselves culturally and spiritually uprooted as a result of World War I and also exploring the meaning of marriage. In this sense, her outlook as she expresses it in The Age of Innocence does not seem radically different than, or even anticipates, that of Hemingway or Fitzgerald, who are in a certain sense her literary heirs. The subtle yet conscious focalization Wharton employs throughout The Age of Innocence, and the depth of characterization this enables, is neatly divided between these writers, Hemingway inheriting her wartime dramatic ambiguity and willingness to expand gender roles, as he did in The Sun Also Rises (1926), ${ }^{68}$ and Fitzgerald, practically a Whartonian character himself, taking her idea of the transactional values within a marriage to its artistic height in Tender is the Night (1934). ${ }^{69}$

\section{Works Cited}

Basch, Françoise. "Women's Rights and the Wrongs of Marriage in Mid-Nineteenth-Century America." History Workshop Journal 22, no. 1 (Autumn 1986): 18 -40. https://doi.org/10. 1093/hwj/22.1.18.

Berger, Peter L. The Sacred Canopy: Elements of a Sociological Theory of Religion. Garden City, NY: Doubleday, 1967.

\footnotetext{
66 Mary Virginia Davis, “Edith Wharton,” in Magill's Survey of American Literature, vol. 6, Steinbeck-Zindel, Appendixes, Indexes, edited by Steven G. Kellman, rev. ed. (Pasadena, CA: Salem Press, 2007), 2663-2667.

67 Lee, Edith Wharton, 450.

68 Ernest Hemingway, The Sun Also Rises (New York: Modern Library, 1926).

69 F. Scott Fitzgerald, Tender is the Night (New York: Scribner, 1934).
} 
Buitenhuis, Peter. "Edith Wharton and the First World War." American Quarterly 18, no. 3 (Autumn 1966): 493-505. https://doi.org/10.2307/2710850.

Davis, Mary Virginia. "Edith Wharton." In Magill's Survey of American Literature, vol. 6, Steinbeck-Zindel, Appendixes, Indexes, edited by Steven G. Kellman, 2663-2667. Revised edition. Pasadena, CA: Salem Press, 2007.

Dupree, Ellen. "The New Woman, Progressivism, and the Woman Writer in Edith Wharton's 'The Fruit of the Tree."' American Literary Realism, 1870-1910 31, no. 2 (Winter 1999): $44-62$.

Elaman-Garner, Sevinç. "Contradictory Depictions of the New Woman: Reading Edith Wharton's The Age of Innocence as a Dialogic Novel." European Journal of American Studies 11, no. 2 (Summer 2016). https://doi.org/10.4000/ejas.11552.

Fitzgerald, F. Scott. Tender is the Night. New York: Scribner, 1934.

Gifford, Sanford. "The Psychoanalytic Movement in the United States, 1906-1991." In History of Psychiatry and Medical Psychology, edited by Edwin R. Wallace and John Gach, 629-656. New York: Springer, 2008. https://doi.org/10.1007/978-0-387-34708-0_21.

Gilbert, Sandra M., and Susan Gubar. The Madwoman in the Attic: The Woman Writer and the Nineteenth-Century Literary Imagination. New Haven, CT: Yale University Press, 1979.

Gollin, Rita K. "Hawthorne and the Visual Arts." In A Historical Guide to Nathaniel Hawthorne, edited by Larry J. Reynolds, 109-133. Oxford: Oxford University Press, 2001.

Graham, George. "Behaviorism." In Stanford Encyclopedia of Philosophy, edited by Edward N. Zalta. Stanford University, 1997-. Published May 26, 2000. Last modified March 19, 2019. https://plato.stanford.edu/archives/spr2019/entries/behaviorism/.

Hawthorne, Nathaniel. “The Minister's Black Veil.” 1836. In Twice-Told Tales, 37-53. Vol. 9 of The Centenary Edition of the Works of Nathaniel Hawthorne, edited by William Charvat, Roy Harvey Pearce, and Claude M. Simpson. 23 vols. Columbus: Ohio State University Press, $1962-97$.

Hawthorne, Nathaniel. The Marble Faun. 1860. Vol. 9 of The Centenary Edition of the Works of Nathaniel Hawthorne, edited by William Charvat, Roy Harvey Pearce, and Claude M. Simpson. 23 vols. Columbus: Ohio State University Press, 1962-1997.

Hawthorne, Nathaniel, The Scarlet Letter. 1850. Vol. 1 of The Centenary Edition of the Works of Nathaniel Hawthorne, edited by William Charvat, Roy Harvey Pearce, and Claude M. Simpson. 23 vols. Columbus: Ohio State University Press, 1962-1997.

Hawthorne, Nathaniel, "Young Goodman Brown." 1835. In Mosses from an Old Manse, 74-90. Vol. 10 of The Centenary Edition of the Works of Nathaniel Hawthorne, edited by William Charvat, Roy Harvey Pearce, and Claude M. Simpson. 23 vols. Columbus: Ohio State University Press, 1962-1997.

Hemingway, Ernest. The Sun Also Rises. New York: Modern Library, 1926.

Irving, Washington. "Rip Van Winkle.” In The Sketch Book of Geoffrey Crayon. 1819-20. Reprinted in The Legend of Sleepy Hollow and Other Stories: Or, The Sketch Book of Geoffrey Crayon, Gent. Introduction by Alice Hoffman. New York: Random House, 2001. Killoran, Helen. The Critical Reception of Edith Wharton. Rochester, NY: Camden House, 2001. Knights, Pamela. "Forms of Disembodiment: The Social Subject in The Age of Innocence." In The Cambridge Companion to Edith Wharton, edited by Millicent Bell, 20-46.

Cambridge: Cambridge University Press, 1995.

Lee, Hermione. Edith Wharton. New York: Vintage Books, 2008. 
Lewis, Richard Warrington Baldwin. Edith Wharton: A Biography. New York: Harper \& Row, 1975.

McDowell, Margaret B. "Viewing the Custom of Her Country: Edith Wharton's Feminism." Contemporary Literature 15, no. 4 (Autumn 1974): 521-538. https://doi.org/10.2307/ 1207776.

Orlando, Emily J. Edith Wharton and the Visual Arts. Tuscaloosa: University of Alabama Press, 2007.

Pride, Mike. "Edith Wharton's 'The Age of Innocence' Celebrates its 100th Anniversary." The Pulitzer Prizes. Accessed February 22, 2021. https://www.pulitzer.org/article/edith-whar tons-age-innocence-celebrates-its-100th-anniversary.

Rakos, Richard F. “John B. Watson's 1913 'Behaviorist manifesto': Setting the Stage for Behaviorism's Social Action Legacy.” Revista Mexicana de Análisis de la Conducta 39, no. 2 (2013): 99-118.

"Real Roman Punch: How a Drink Made Exclusively for the Pope Became General." Morning Union 44, no. 5956. February 7, 1890. https://cdnc.ucr.edu/?a=d\&d=MU18900207.2. 3\&e=---en-20--1--txt-txIN--1.

Resseguie, Harry E. "Alexander Turney Stewart and the Development of the Department Store, 1823-1876," Business History Review 39, no. 3 (Autumn 1965): 301-322. https:// doi.org/10.2307/3112143.

Sherwood, Mary Elizabeth Wilson. Manners and Social Usages. New York: Harper \& Brothers, 1887.

Showalter, Elaine. Sexual Anarchy: Gender and Culture at the Fin de Siècle. New York: Penguin Books, 1991.

Singley, Carol J., ed. A Historical Guide to Edith Wharton. Oxford: Oxford University Press, 2003.

Singley, Carol J., and Susan Elizabeth Sweeney, eds. Anxious Power: Reading, Writing, and Ambivalence in Narrative by Women. New York: State University of New York Press, 1993.

Strout, Cushing. “Complementary Portraits: James's Lady and Wharton's Age." In Edith Wharton's The Age of Innocence, edited by Harold Bloom, 3-11. Philadelphia, PA: Chelsea House Publishers, 2005.

Wharton, Edith, The Age of Innocence. New York: Penguin Classics, 1996 [1920].

Wharton, Edith. The House of Mirth. New York: Charles Scribner's Sons, 1905.

Wharton, Edith. “A Little Girl's New York.” Harper's Magazine 176 (March 1938): 356-364. Reprinted in The Age of Innocence: A Norton Critical Edition, edited by Candace Waid, 232-247. New York: W. W. Norton, 2002.

Wharton, Edith. The Writing of Fiction. New York: Charles Scribner's Sons, 1925.

Wharton, Edith, and Ogden Codman Jr. The Decoration of Houses. New York: Charles Scribner's Sons, 1897.

Wolff, Cynthia Griffin. A Feast of Words: The Triumph of Edith Wharton. New York: Oxford University Press, 1977.

Young, John H. Our Deportment; or, The Manners, Conduct and Dress of the Most Refined Society. New York: F. B. Dickerson \& Co, 1885. 